\title{
PENINGKATAN PRESTASI BELAJAR MAHASISWA DENGAN MENCIPTAKAN LINGKUNGAN BELAJAR YANG KONDUSIF
}

\author{
Anton Budi Santoso', Shinta Oktafien² \\ ${ }^{1}$ Fakultas Bisnis \& Manajemen, Universitas Widyatama Bandung \\ Email:anton.budi@widyatama.ac.id \\ ${ }^{2}$ Fakultas Bisnis \& Manajemen, Universitas Widyatama Bandung \\ Email: shinta.oktafien@widyatama.ac.id
}

\begin{abstract}
ABSTRAK
Lingkungan belajar dapat didefinisikan sebagai tempat di mana mahasiswa melakukan kegiatan belajar dan bersosialisasi dengan orang lain yang ada di lingkungan tersebut. Menciptakan lingkungan belajar yang kondusif dapat berpengaruh terhadap prestasi belajar mahasiswa yang semakin meningkat karena bilamana mahasiswa merasa nyaman melakukan proses belajar mengajar di kampusnya sendiri, maka semangat mahasiswa tersebut untuk menyelesaikan masa perkuliahannya menjadi semakin tinggi, sehingga dengan sendirinya dapat berpengaruh terhadap hasil belajar yang semakin lebih baik. Adapun yang menjadi tujuan dilakukannya penelitian ini adalah untuk mengetahui sampai seberapa besar pengaruh lingkungan belajar terhadap prestasi belajar mahasiswa yang menempuh mata kuliah Etika Bisnis kelas A pada semester Genap TA. 2016/2017. Untuk metode penelitian yang digunakan dalam penelitian ini merupakan metode asosiatif dengan jenis penelitian survey yang informasi dan data yang berhubungan dengan masalah yang diteliti dikumpulkan daftar pertanyaan tertulis/ kuesioner yang dibagikan kepada para mahasiswa Prodi. Manajemen D3, terutama mahasiswa yang mengambil mata kuliah Etika Bisnis kelas A sebagai respondennya, dengan jumlah sampel sebanyak 27 orang mahasiswa dan untuk teknik pengolahan dan analisis data digunakan analisis regresi linier berganda yang perhitungannya sendiri dilakukan dengan menggunakan bantuan program SPSS versi 21.0. Berdasarkan hasil perhitungan dan pengolahan data, diketahui bahwa tidak adanya pengaruh yang berarti atau signifikan di antara kedua variabel yang diteliti dalam penelitian ini yang berarti bahwa peningkatan prestasi belajar mahasiswa tidak selalu ditentukan oleh faktor penciptaan lingkungan belajar yang kondusif.
\end{abstract}

Kata kunci: lingkungan keluarga, lingkungan sekolah, lingkungan masyarakat, prestasi belajar

\section{PENDAHULUAN}

Pada dasarnya, setiap manusia dalam hidupnya selalu mengalami proses belajar. Dimulai semenjak orang tersebut dilahirkan sampai dengan saat ini dan seterusnya setiap waktu orang akan belajar mengenai apa yang terjadi pada dirinya dan lingkungan yang ada di sekitarnya. Oleh sebab itu, boleh dikatakan bahwa proses belajar dapat menjadi sesuatu hal yang bersifat inheren, dalam arti akan selalu melekat pada setiap individu manusia, di samping proses belajar pun dapat saja berpengaruh pada perilaku kerja yang ditunjukkan oleh tiap-tiap individu tersebut yang bisa berbeda-beda. Dengan demikian, dapat dikatakan pula bahwa adanya perbedaan perilaku, sikap, pandangan, motif, ataupun persepsi yang dimiliki oleh tiaptiap orang dapat disebabkan oleh hasil proses belajar yang dialami oleh orang tersebut. Meskipun demikian, tidak selalu setiap proses belajar dapat berpengaruh terhadap perubahan sikap atau perilaku seseorang pada saat melakukan suatu pekerjaan, termasuk dalam hal prestasi belajar mahasiswa yang tidak selalu mahasiswa mampu mendapatkan prestasi yang baik pada saat menjalani masa perkuliahannya.

Bagi perguruan tinggi, Nilai Akhir Semester pada suatu mata kuliah dapat menjadi salah satu cara dalam mengukur prestasi belajar mahasiswa selama menjalani masa perkuliahannya. Nilai Akhir Semester suatu mata kuliah merupakan gabungan dari beberapa nilai hasil evaluasi selama satu semester yang terdiri dari beberapa komponen nilai, di antaranya Nilai 
Ujian Tengah Semester (UTS), Nilai Ujian Akhir Semester (UAS), nilai hasil evaluasi lainnya yang diselenggarakan oleh masing-masing dosen yang bersangkutan, seperti kuis, responsi, atau pengerjaan tugas-tugas yang berupa makalah, pemecahan soal/kasus dan sebagainya, dan nilai absensi atau kehadiran mahasiswa tatap muka di kelas. Nilai akhir semester suatu mata kuliah yang diperoleh oleh mahasiswa ini dinyatakan dengan huruf mutu yang masing-masing mempunyai sebutan dan angka mutu tertentu. Universitas Widyatama, sebagai salah satu universitas swasta terbaik di kota Bandung, memiliki Sasaran Mutu Universitas yang salah satu di antaranya menyatakan bahwa sekurang-kurangnya $75 \%$ mahasiswa dapat lulus tepat pada waktunya dengan memiliki prestasi yang sangat memuaskan, yakni IPK di atas 2,75, yang dapat diperoleh bilamana mahasiswa mampu mendapatkan nilai akhir semester pada setiap mata kuliah yang ditempuh sekurang-kurangnya dengan nilai B.

Tidak selalu mahasiswa pada saat menjalani kegiatan perkuliahannya mampu lulus dan mendapatkan nilai akhir semester dengan angka yang memuaskan untuk setiap mata kuliah yang diambilnya. Misalkan saja, untuk Semester Genap TA. 2016/2017 ini, diketahui bahwa sebesar 44\% mahasiswa mendapatkan nilai di bawah angka 67 yang berarti bahwa masih banyak mahasiswa yang belum mampu memperoleh nilai akhir semester yang baik, yakni lulus dengan sekurang-kurangnya mendapatkan huruf mutu "B" untuk setiap mata kuliah yang diambil pada semester genap tersebut. Oleh sebab itu, perlu sekiranya dapat dicari tahu apa yang bisa menjadi penyebab mahasiswa pada saat menjalani perkuliahan pada setiap semesternya masih banyak yang memiliki nilai akhir semester yang tidak memuaskan, atau dengan kata lain prestasi belajar yang kurang begitu baik.

Tabel 1. Rekapan Nilai Akhir Semester Mahasiswa Prodi. Manajemen D3 Semester Genap TA. 2016/2017

\begin{tabular}{cc}
\hline Huruf Mutu & $\%$ \\
\hline A & 27 \\
\hline B & 29 \\
\hline C & 17 \\
\hline D & 6 \\
\hline E & 4 \\
\hline K & 27 \\
\hline T & 0 \\
\hline
\end{tabular}

Sumber: Biro Administrasi Akademik

Prestasi belajar dapat didefinisikan sebagai hasil belajar yang dicapai oleh mahasiswa dengan kriteria tertentu (Nana Sudjana, 2005). Adapun faktor-faktor yang berpengaruh terhadap hasil belajar mahasiswa dapat dibedakan menjadi dua faktor, di antaranya (Slameto, 2010): 1) faktor intern, yakni faktor-faktor yang bersumber dari dalam diri seseorang yang terdiri dari faktor jasmaniah (faktor kesehatan, cacat tubuh), faktor psikologis (intelegensi, perhatian, minat, bakat, motif, kematangan, dan kesiapan), dan faktor kelelahan, dan 2) faktor ekstern, yaitu faktor-faktor yang bersumber dari luar diri seseorang yang terdiri dari faktor keluarga (cara orang tua mendidik, relasi antar anggota keluarga, suasana rumah tangga, keadaan ekonomi keluarga), faktor sekolah (metode belajar, kurikulum, relasi pengajar dengan pengajar, relasi siswa dengan siswa, disiplin sekolah, pengajaran dan waktu sekolah, standar pelajaran, keadaan gedung, metode Belajar, tugas rumah), dan faktor masyarakat (kegiatan siswa dalam masyarakat, mass media, teman bergaul, dan bentuk kehidupan masyarakat).

Menciptakan lingkungan belajar yang kondusif dapat menjadi salah satu faktor yang dapat berpengaruh terhadap peningkatan prestasi belajar mahasiswa. Yang dimaksud dengan lingkungan belajar, dalam hal ini berarti lingkungan kampus yang kondusif, merupakan tempat di mana mahasiswa melakukan kegiatan belajar dan bersosialisasi dengan orang lain 
yang ada di lingkungan tersebut (Mustafa Setyo Aribowo, 2012). Lingkungan belajar merupakan segala sesuatu yang terdapat di tempat belajar (Hutabarat, 1985). Oleh sebab itu, penting bagi institusi perguruan tinggi untuk menciptakan lingkungan kampus yang kondusif karena bilamana mahasiswa merasa nyaman melakukan proses belajar mengajar di kampusnya sendiri, maka semangat mahasiswa tersebut untuk menyelesaikan masa perkuliahannya menjadi semakin tinggi, sehingga dengan sendirinya dapat berpengaruh terhadap hasil belajar yang semakin lebih baik. Sebaliknya, apabila mahasiswa merasa tidak nyaman dengan kondisi lingkungan kampus tempatnya belajar, maka mahasiswa tersebut dapat memiliki motivasi belajar yang semakin menurun yang pada akhirnya dapat berdampak pada prestasi kerja yang menjadi tidak baik.

Berdasarkan pada latar belakang itulah peneliti merasa tertarik untuk melakukan penelitian dengan judul "Peningkatan Prestasi Belajar Mahasiswa dengan Menciptakan Lingkungan Belajar yang Kondusif" (Suatu Studi pada Mahasiswa Mata Kuliah Etika Bisnis Kelas A Prodi. Manajemen D3 pada Semester Genap TA. 2016/2017).

\section{METODE PENELITIAN}

\section{Metodologi penelitian}

Metode penelitian yang digunakan dalam penelitian ini merupakan penelitian asosiatif, yaitu jenis penelitian yang dilakukan dengan maksud untuk mengetahui hubungan di antara dua atau lebih dari dua variabel dengan maksud untuk menemukan variabel penting mana yang berkaitan dengan masalah yang diteliti. Dalam penelitian ini peneliti akan mencari tahu dan menganalisis hubungan diantara variabel-variabel yang terdiri dari variabel lingkungan belajar yang kondusif (X) sebagai variabel bebas/ independen dengan variabel prestasi belajar mahasiswa (Y) sebagai variabel terikat/ dependen.

Untuk metode penelitian yang digunakan dalam penelitian ini adalah metode penelitian survei, dimana informasi dan data yang berhubungan dengan masalah yang diteliti dikumpulkan melalui daftar pertanyaan tertulis/ kuesioner yang dibagikan kepada para mahasiswa Prodi. Manajemen D3, terutama mahasiswa yang mengambil mata kuliah Etika Bisnis kelas A sebagai respondennya.

\section{Operasional variabel}

Dalam penelitian ini terdapat 2 (dua) variabel utama yang diteliti, di antaranya "menciptakan lingkungan belajar yang kondusif (X)" sebagai variabel bebas/ independen dan "peningkatan prestasi belajar mahasiswa (Y)" sebagai variabel terikat/ dependen.

\section{Populasi dan sampel}

Adapun yang menjadi populasi dalam penelitian ini adalah seluruh mahasiswa Prodi. Manajemen D3 yang menempuh mata kuliah Etika Bisnis kelas A pada Semester Genap TA. 2016/2017 yang berjumlah sebanyak 27 orang dengan jumlah sampel yang diambil, yaitu sebanyak keseluruhan dari jumlah populasi mahasiswa yang ada yang dijadikan sebagai respondennya. Oleh sebab itu, sampel yang digunakan merupakan sampel jenuh atau sensus yang merupakan teknik pengambilan sampel bilamana semua anggota populasi yang ada dijadikan sebagai sampelnya. 


\section{Teknik pengumpulan data}

Pengumpulan data dilakukan melalui cara pembagian kuesioner yang dibagikan kepada para mahasiswa mahasiswa Prodi. Manajemen D3 yang menempuh mata kuliah Etika Bisnis kelas A pada Semester Genap TA. 2016/2017 yang menjadi responden dalam penelitian ini. Adapun skala yang digunakan dalam kuesioner ini berupa skala interval dengan jenis pengukuran skala yang digunakan adalah skala Likert, yang mana responden nantinya akan diminta untuk menetapkan sikap atas berbagai pernyataan yang ada pada kuesioner tersebut dengan cara memberikan tanda pada opsi jawaban yang telah tersedia.

\section{Teknik pengolahan data}

Untuk pengolahan dan analisis data yang digunakan pada penelitian ini, yakni dilakukan dengan menggunakan analisis regresi linier sederhana yang perhitungannya itu sendiri dilakukan dengan menggunakan bantuan program SPSS versi 21.0.

\section{HASIL DAN PEMBAHASAN}

\section{Hasil pengolahan data}

\section{Uji koefisien korelasi Pearson}

Metode ini digunakan untuk mengetahui apakah ada hubungannya antara variabel penciptaan lingkungan belajar yang kondusif, sebagai variabel bebasnya $(\mathrm{X})$, dengan variabel prestasi belajar mahasiswa, sebagai variabel terikatnya (Y), yang ditujukan kepada para mahasiswa Program Studi Manajemen D3 yang mengambil mata kuliah Etika Bisnis kelas A pada Semester Genap TA. 2016/2017. Berikut ini merupakan tabel yang menunjukkan interpretasi koefisien korelasi yang digunakan untuk mengetahui apakah hubungan di antara kedua variabel tersebut terindikasi kuat atau lemah.

Tabel 2. Interprestasi Koefisien Korelasi

\begin{tabular}{ll}
\hline \multicolumn{1}{c}{ Interval Koefisien Korelasi } & \multicolumn{1}{c}{ Tingkat Hubungan } \\
\hline $0.000-0.199$ & Sangat Rendah \\
\hline $0.200-0.399$ & Rendah \\
\hline $0.400-0.599$ & Sedang \\
\hline $0.600-0.799$ & Kuat \\
\hline $0.800-1.000$ & Sangat Kuat \\
Sumber: Sugiyono, 2008: 216 &
\end{tabular}

Berdasarkan data yang ditunjukkan pada tabel 3, diketahui bahwa keterkaitan di antara variabel yang diteliti menunjukkan nilai koefisien korelasi sebesar -0.274 yang berarti bahwa tidak adanya keterkaitan ataupun hubungan yang signifikan di antara variabel penciptaan lingkungan belajar yang kondusif terhadap peningkatan prestasi belajar mahasiswa. Bahkan, nilai dari hasil perhitungan tersebut menunjukkan bahwa hubungan di antara kedua variabel memiliki arah yang berlawanan atau negatif yang berarti bahwa kenaikan nilai variabel independen $(\mathrm{X})$ justru malah dibarengi dengan penurunan nilai variabel terikatnya $(\mathrm{Y})$, atau sebaliknya. 
Tabel 3. Hasil Analisis Uji Korelasi Penciptaan Lingkungan Belajar yang Kondusif terhadap Peningkatan Prestasi Belajar Mahasiswa

\begin{tabular}{lllrr}
\hline & & \multicolumn{2}{c}{$\begin{array}{c}\text { Lingkungan } \\
\text { Belajar }\end{array}$} & Prestasi Belajar \\
\hline Spearman's rho & Lingkungan Belajar & Correlation Coefficient & 1.000 & -.274 \\
& & Sig. (2-tailed) &. & .166 \\
& $\mathrm{~N}$ & 27 & 27 \\
\cline { 2 - 5 } & & Correlation Coefficient & -.274 & 1.000 \\
& Prestasi Belajar & Sig. (2-tailed) & .166 & $\cdot$ \\
& & $\mathrm{N}$ & 27 & 27 \\
\hline
\end{tabular}

Sumber: Hasil Perhitungan Data Primer

\section{Koefisien determinasi $\left(\mathbf{R}^{2}\right)$}

Koefisien determinasi $\left(\mathrm{R}^{2}\right)$ merupakan cara pengukuran yang digunakan untuk mengetahui sampai seberapa jauh kemampuan model dalam menerangkan variasi variabel bebasnya. Adapun untuk nilai koefisien determinasi berada pada angka antara 0 sampai dengan 1.

Berdasarkan data yang ditunjukkan pada tabel 4, ditunjukkan bahwa nilai koefisien determinasi (adjusted $\mathrm{R}^{2}$ ) yang diperoleh untuk variabel yang diteliti pada penelitian ini hanya memiliki angka sebesar 0.095 yang berarti bahwa hanya $9.5 \%$ saja prestasi belajar mahasiswa yang semakin meningkat dapat dijelaskan oleh penciptaan lingkungan belajar yang kondusif, sebagai salah satu faktor penyebabnya. Dengan demikian, dapat diketahui bahwa pada dasarnya tidak ada pengaruh yang berarti yang dapat menjelaskan keterkaitan atau pengaruhnya di antara kedua variabel yang diteliti

Tabel 4. Koefisiensi Determinasi $\left(\mathrm{R}^{2}\right)$ Pengaruh Penciptaan Lingkungan Belajar yang Kondusif terhadap Peningkatan Prestasi Belajar Mahasiswa

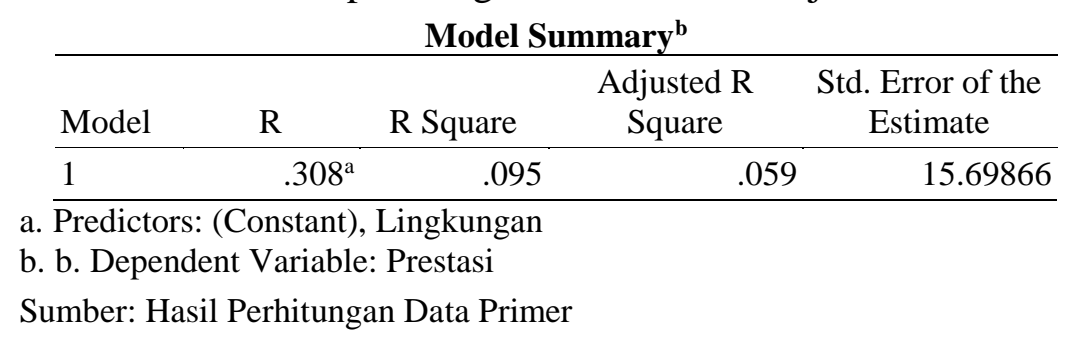

\section{Analisis regresi linear}

Dalam penelitian ini, untuk mengetahui apakah ada pengaruhnya antara variabel penciptaan lingkungan belajar yang kondusif, sebagai varaiabel bebas $(\mathrm{X})$, dengan variabel prestasi belajar mahasiswa, sebagai variabel terikat $(\mathrm{Y})$, digunakan metode analisis regresi linear sederhana yang perhitungan statistiknya dilakukan dengan menggunakan bantuan program software SPSS versi 21.0. Berdasarkan pada hasil analisis data yang ditunjukkan pada tabel 5, diketahui bahwa untuk model persamaan regresi liniear sederhana yang terbentuk adalah sebagai berikut: 
Tabel 5. Hasil Regresi Linear Sederhaan Pengaruh Penciptaan Lingkungan Belajar yang Kondusif terhadap Prestasi Belajar Mahasiswa Coefficients $^{\mathrm{a}}$

\begin{tabular}{|c|c|c|c|c|c|c|}
\hline \multirow[b]{2}{*}{ Model } & & \multicolumn{2}{|c|}{ Unstandardized Coefficients } & \multirow{2}{*}{$\begin{array}{c}\text { Standardized } \\
\text { Coefficients } \\
\text { Beta } \\
\end{array}$} & \multirow[b]{2}{*}{$\mathrm{t}$} & \multirow[b]{2}{*}{ Sig. } \\
\hline & & B & Std. Error & & & \\
\hline \multirow[t]{2}{*}{1} & (Constant) & 115.774 & 31.177 & & 3.713 & .001 \\
\hline & Lingkungan & -1.037 & .641 & -.308 & -1.618 & .118 \\
\hline
\end{tabular}

a. Dependent Variable: Prestasi

Sumber: Hasil Perhitungan Data Primer

Berdasarkan pada hasil persamaan regresi sederhana tersebut, diketahui bahwa pengaruh penciptaan lingkungan belajar yang kondusif terhadap prestasi belajar mahasiswa dapat diinterprestasikan sebagai berikut:

- Jika nilai variabel $\mathrm{X}$ sama dengan (0), maka nilai dari variabel $\mathrm{Y}=115.774$

- Jika nilai variabel X mengalami kenaikan sebesar angka 1 (satu), maka nilai variabel Y akan mengalami penurunan sebesar 1.037.

$$
\mathrm{Y}=115.774+(-1.037 \mathrm{X})+\dot{\varepsilon}
$$

\section{Perhitungan uji hipotesis}

Hipotesis utama yang dimiliki pada penelitian ini disebutkan bahwa terdapat pengaruh yang signifikan antara penciptaan lingkungan belajar yang kondusif terhadap prestasi belajar mahasiswa. Berdasarkan pada hipotesis yang telah dikemukakan tersebut, maka langkah selanjutnya dilakukan uji hipotesis yang bertujuan untuk mencari jawaban apakah hipotesis yang ada dapat diterima atau justru malah ditolak yang dihitung dengan menggunakan rumus statistik uji $\mathrm{F}$ yang ditujukan untuk menguji signifikansi antara kedua variabel yang diteliti.

Berdasarkan hasil perhitungan yang ditunjukkan pada tabel 6 , diketahui bahwa nilai $F_{\text {hitung }}$ memiliki nilai yang lebih kecil dibandingkan dengan nilai $F_{\text {tabel }}$ atau $2.619<4.242$, sehingga dapat disimpulkan bahwa apabila nilai $\mathrm{F}_{\text {hitung }}$ lebih kecil dari nilai $\mathrm{F}_{\text {tabel, }}$, maka $\mathrm{H}_{0}$ diterima yang berarti bahwa tidak adanya pengaruh yang signifikan atau berarti antara penciptaan lingkungan belajar yang kondusif dengan prestasi belajar mahasiswa.

Tabel 6. Uji Hipotesis

ANOVA $^{\mathrm{b}}$

\begin{tabular}{llrrrrr}
\hline Model & & Sum of Squares & df & Mean Square & F & \multicolumn{1}{c}{ Sig. } \\
\hline 1 & Regression & 645.472 & 1 & 645.472 & 2.619 & $.118^{\mathrm{a}}$ \\
\cline { 2 - 7 } & Residual & 6161.194 & 25 & 246.448 & & \\
\cline { 2 - 7 } & Total & 6806.667 & 26 & & & \\
\hline
\end{tabular}

a. Predictors: (Constant), Lingkungan

b. Dependent Variable: Prestasi

Sumber: Hasil Perhitungan Data Primer

\section{Pembahasan}

Berdasarkan pada hasil perhitungan dan pengolahan data, diketahui bahwa hasil yang diperoleh menunjukkan tidak adanya pengaruh yang berarti atau signifikan di antara kedua 
variabel yang diteliti pada penelitian ini. Dengan demikian diketahui bahwa penciptaan lingkungan belajar yang kondusif bukanlah merupakan faktor yang dapat menentukan semakin meningkat atau menurunnya prestasi belajar mahasiswa. Kondisi yang seperti ini tentunya memiliki hasil yang berbeda dengan penelitian-penelitian yang memiliki topik serupa, di antaranya seperti penelitian yang dilakukan oleh Mustofa Setyo Ariwibowo (2012) mengenai keterkaitan antara lingkungan belajar dengan prestasi belajar mahasiswa yang menunjukkan adanya pengaruh yang positif dan signifikan di antara kedua variabel yang diteliti tersebut. Begitu pula dengan penelitian lainnya yang dilakukan oleh Widyaningtyas, Sukarmin, dan Radiyono (2013) yang membahas peran lingkungan belajar dan kesiapan belajar terhadap prestasi belajar yang menunjukkan adanya pengaruh yang signifikan di antara variabel-variabel yang diteliti. Penelitian lainnya yang dikemukakan oleh Singgih Tego Saputro dan Pardiman (2012) menyebutkan bahwa ada pengaruh yang positif dan signifikan antara lingkungan teman sebaya terhadap prestasi belajar mahasiswa.

\section{KESIMPULAN DAN SARAN}

Berdasarkan hasil penelitian dan pembahasan yang telah dikemukakan sebelumnya, disimpulkan bahwa penciptaan lingkungan belajar yang kondusif tidak berpengaruh secara signifikan terhadap peningkatan prestasi belajar mahasiswa.

Penulis menyadari bahwa penelitian yang telah dilakukannya ini masih jauh dari kata sempurna. Oleh sebab itu, agar ke depan penelitian ini dapat menjadi semakin lebih baik lagi perlu disarankan bahwa ada baiknya jumlah sampel yang dikumpulkan dapat menjadi semakin lebih banyak, sehingga hasilnya pun dapat mewakili jumlah populasi penelitian yang ada. Di samping itu, perlu untuk dipertimbangkan pula mengenai dimunculkannya variabelvariabel lainnya yang sekiranya masih memiliki keterkaitan ataupun hubungannya dengan topik yang diteliti pada penelitian ini, seperti variabel kesiapan belajar, motivasi belajar dan variabel lainnya.

\section{Ucapan Terima Kasih (Acknowledgement)}

Bersama dengan ini, penulis ingin mengucapkan terima kasih kepada pihak-pihak yang mendukung penelitian ini, di antaranya yang ditujukan kepada Ka. Prodi. Manajemen D3 Fakultas Bisnis \& Manajemen Universitas Widyatama yang atas seizinnya penulis dapat menyelesaikan penelitian sederhana ini dengan baik, sehingga hasilnya pun berharap dapat dijadikan sebagai masukan yang berguna bagi institusi kampus UTama, khusus pada Program Studi Manajemen D3, yang berkaitan dengan upaya meningkatkan prestasi belajar para mahasiswanya yang dilakukan dengan menciptakan lingkungan belajar yang kondusif.

\section{REFERENSI}

Ariwibowo, M.S. (2012). Pengaruh Lingkungan Belajar terhadap Prestasi Belajar Mahasiswa PPKn Angkatan 2008/2009 Universitas Ahmad Dahlan Semester Ganjil Tahun Akademik 2010/2011. Jurnal Citizenship, 1, 113-122.

Hadi, S. (2003). Pengantar Pendidikan. Surakarta: UNS Pres.

Hariandja, M. T. E. (2006). Perilaku Organisasi: Memahami dan Mengelola Perilaku dalam Organisasi. Bandung: UNPAR Press.

Hutabarat, S.P. (1995). Cara Belajar. Jakarta: BPR Gunung Mulia.

Muhidin, A. S., dan Abdurahman, M. (2009). Analisis Korelasi, Regresi, dan Jalur dalam 
Penelitian [Dilengkapi Aplikasi Program SPSS]. Bandung: Pustaka Setia.

Nasution, N. (2004). Psikologi Belajar. Jakarta: Gramedia Pustaka Utama.

Robbins, S. P. (2006). Organizational Behavior (10 th ed.) (Benyamin Molan, Penerjemah). Jakarta: PT. INDEKS, Kelompok Gramedia.

Saputro, S.T., \& Pardiman. (2012). Pengaruh Disiplin Belajar dan Lingkungan Teman Sebaya terhadap Prestasi Belajar Mahasiswa Program Studi Pendidikan Akuntansi Angkatan 2009 Fakultas Ekonomi Universitas Negeri Yogyakarta. Jurnal Pendidikan Akuntansi Indonesia, 10, 78-97.

Sardiman, A.M. (2011). Interaksi \& Motivasi Belajar Mengajar. Jakarta: Rajagrafindo.

Slameto. (2010). Belajar dan Faktor-faktor yang Mempengaruhinya. Jakarta: Rineka Cipta.

Sudjana, N. (2005). Dasar-dasar Proses Belajar Mengajar. Bandung: Remaja Rosdakarya.

n.d. (2005). Penilaian Hasil Proses Belajar Mengajar. Bandung: Remaja Rosdakarya.

Sugiono. (2008). Metode Penelitian Bisnis. Andung: Alfabeta.

Syah, M. (2006). Psikologi Belajar. Jakarta: Rajagrafindo.

Widyaningtyas, A. S., \& Radiyono, Y. (2013). Peran Lingkungan Belajar dan Kesiapan Belajar terhadap Prestasi Belajar Fisika Kela X Sekolah Menengah Atas Negeri 1 Pati. Jurnal Pendidikan Fisika, 1, 136-143.

Biro Akademik Widyatama. 2012. http://akademik.widyatama.ac.id/buku-panduan/indeksprestasi-kumulatif-ipk/. Accessed on 10 April 2016. 